\title{
Kontribusi Konsep Diri, Motivasi Belajar Dan Minat Belajar Terhadap Prestasi Belajar IPS Siswa SMP N 1 Mengwi
}

\author{
Komang Budi Ariani ${ }^{*}$, Sukadi ${ }^{1}$, I Wayan Kertih ${ }^{1}$ \\ 1 Universitas Pendidikan Ganesha, Indonesia \\ *e-mail: budiariani1192@gmail.com
}

Article history: Received 08 July 2021; Accepted 27 July 2021; Available online 31 August 2021

\begin{abstract}
Abstrak
Tujuan dari penelitian ini adalah untuk mengetahui kontribusi konsep diri, motivasi belajar dan minat belajar terhadap prestasi belajar IPS siswa SMP N 1 Mengwi tahun pelajaran 2020/2021. Penelitian ini termasuk penelitian Survey Studi Korelasi. Populasi berjumlah 1.047 siswa, sedangkan sample digunakan 285 siswa. Variabel bebas pada penelitian ini meliputi: konsep diri, motivasi belajar, dan minat belajar, sedangkan sebagai variabel terikat adalah prestasi belajar IPS. Metode pengumpulan data menggunakan metode kuesioner dan studi dokumen. Analisis data yang digunakan adalah analisis regresi ganda. Berdasarkan penelitian yang telah dilakukan, dapat disimpulkan bahwa: terdapat kontribusi yang signifikan konsep diri, motivasi belajar, dan minat belajar terhadap prestasi belajar IPS siswa baik secara terpisah maupun secara bersama-sama, dengan kontribusi sebesar $61,81 \%$. Implikasi dari penelitian ini adalah penelitian ini memberikan pemahaman bagi guru, bahwa sangat penting memperhatikan konsep diri, motivasi belajar, dan minat belajar siswa dalam proses belajar, agar tujuan pembelajaran dapat tercapai secara maksimal.
\end{abstract}

\section{Abstract}

The purpose of this study was to determine the contribution of self-concept, learning motivation, and interest in social studies learning achievement of SMP N 1 Mengwi students in the 2020/2021 school year. This research includes a Correlation Study Survey research. The population is 1,047 students, while the sample used is 285 students. The independent variables in this study include self-concept, learning motivation, and interest in learning, while the variable as a determinant is social studies learning achievement. Methods of data collection using questionnaires and document studies. Analysis of the data used is multiple regression analysis. Based on the research that has been done, it can be said that: there is a significant contribution to social studies learning both separately and together, with a contribution of $61.81 \%$. The implication of this research is in providing an understanding for teachers that it is crucial to pay attention to self-concept, learning motivation, and student interest in learning in the learning process so that learning objectives can be achieved optimally.

\section{Kata Kunci:}

Konsep Diri; Motivasi

Belajar; Minat

Belajar;Prestasi Belajar

IPS

\section{Keywords:}

Self-Concept; Learning Motivation; İnterest İn Learning; Social Studies Learning Achievement 


\section{Pendahuluan}

Pendidikan sebagai sebuah proses pengembangan sumberdaya manusia agar memperoleh kemampuan sosial dan perkembangan individu yang optimal memberikan relasi yang kuat antara individu dengan masyarakat dan lingkungan budaya sekitarnya. Lebih dari itu pendidikan merupakan proses "memanusiakan manusia" dimana manusia diharapkan mampu memahami dirinya, orang lain, alam dan lingkungan budayanya (dalam Ibrahim, 2000:3). Undang-Undang (UU) Sistem Pendidikan Nasional (Sisdiknas) No. 20 Tahun 2003 pasal 1 ayat 1 menyebutkan bahwa: Pendidikan adalah usaha sadar dan terencana untuk mewujudkan suasana belajar dan proses pembelajaran agar peserta didik secara aktif mengembangkan potensi dirinya untuk memiliki kekuatan spiritual keagamaan, pengendalian diri, kepribadian, kecerdasan, akhlak mulia, serta keterampilan yang diperlukan dirinya, masyarakat, bangsa dan Negara.

Pendidikan merupakan sarana penting untuk meningkatkan kualitas sumber daya manusia. Semakin baik kualitas pendidikan maka akan semakin baik pula kualitas sumber daya manusia yang dihasilkan begitu pula sebaliknya (Rusmini, 2017:80). Sistem pendidikan di Indonesia telah mengalami banyak perubahan. Perubahan-perubahan ini terjadi karena telah dilakukan berbagai usaha pembaharuan dalam pendidikan.Sejalan dengan kemajuan tersebut, maka dewasa ini pendidikan di sekolah-sekolah telah menunjukkan perkembangan yang sangat pesat. Perkembangan itu terjadi karena terdorong adanya pembaharuan, sehingga dalam pembelajaran guru harus menemukan metode dan pendekatan yang baru yang dapat memberikan semangat belajar bagi semua siswa.

Sekolah merupakan tempat melaksanakan proses pembelajaran secara formal. Di sekolah terjadi interaksi antara pendidik dengan peserta didik. Proses pembelajaran di sekolah tentunya harus direncanakan secara matang. Oleh karena itu diperlukan sebuah pedoman dalam menjalankan proses pembelajaran. Dengan adanya pedoman, maka proses pembelajaran dapat berlangsung secara baik. Proses pembelajaran di sekolah dilaksanakan dengan berpedoman pada kurikulum.

Kurikulum merupakan pedoman pembelajaran yang diturunkan oleh pusat. Kurikulum dapat berubah sesuai dengan perkembangan zaman. Perubahan Kurikulum tersebut didasari pada kesadaran bahwa perkembangan dan perubahan yang terjadi menuntut perlunya perbaikan sistem pendidikan nasional, termasuk penyempurnaan kurikulum untuk mewujudkan masyarakat yang mampu bersaing dan menyesuaikan diri dengan perubahan. Karena tidak bisa dipungkiri perubahan di dunia saat ini sangatlah cepat di segala bidang, tidak terkecuali dalam bidang pendidikan. Oleh sebab itu, diperlukan kesiapan untuk menghadapi setiap perubahan yang ada.

Salah satu mata pelajaran yang ada pada kurikulum di Sekolah Menengah Pertama adalah mata pelajaran Ilmu Pengetahuan Sosial. Menurut Raga (2006:1), Ilmu Pengetahuan Sosial merupakan mata pelajaran yang memadukan konsep-konsep dasar dari berbagai ilmu sosial yang disusun melalui pendekatan pendidikan dan psikologis serta keyakinan dan kebermaknaannya bagi siwa dan kehidupannya. Menurut Leonard (dalam Rahmad, 2016:71) mengemukakan bahwa IPS menggambarkan interaksi individu atau kelompok dalam masyarakat baik dalam lingkungan mulai dari yang terkecil misalkan keluarga, tetangga, rukun tetangga atau rukun warga, desa/kelurahan, kecamatan, kabupaten, provinsi, negara dan dunia. Jadi dari pendapat para ahli diatas dapat dikatakan bahwa IPS merupakan suatu mata pelajaran yang memadukan konsepkonsep sosial yang berhubungan dengan geografi, sejarah, sosiologi dan ekonomi. Serta IPS memegang pembelajaran tentang hubungan manusia dengan lingkungan sosial. 
Sedangkan Ilmu Pengetahuan Sosial (IPS) menurut Susanto (2014;6-7) adalah integrasi dari berbagai cabang ilmu-ilmu sosial dan humaniora, yaitu sosiologi, sejarah, geografi, ekonomi, politik, hukum, dan budaya. Pelajaran IPS di SD mengajarkan konsep-konsep esiensi ilmu sosial untuk membentuk subjek didik menjadi warga negara yang baik. IPS bukan hanya mengajarkan pengetahuan sosial secara konsep keilmuan, tetapi juga makna dari konsep-konsep ilmu sosial, kemaslahatan kehidupan manusia, berbagai kemampuan yang dibutuhkan manusia dalam kehidupannya dan lebih menekankann pada pendidikan sesama tentang sosial kemasyarakatan. IPS merupakan bagian penting dalam menghadapi masalah kehidupan sosial yang terjadi pada setiap manusia dan masyarakat dalam kehidupan. Kehidupan masyarakat senantiasa mengalami perubahan-perubahan dari waktu ke waktu.

Pembelajaran IPS diharapkan mampu membentuk sikap siswa menjadi lebih aktif, memiliki sikap sosial yang baik, saling menghargai dan menjadi warga Negara yang baik dalam kehidupan sosial di masyarakat. Siswa akan mudah berinterkasi dengan orang lain, diterima dalam masyarakat. Siswa juga dapat mengenal tentang hubungan antara manusia dengan lingkungan hidupnya, memahami perubahan-perubahan yang terjadi di sekitarnya, memahami bahwa antara manusia yang satu dengan yang lain saling membutuhkan, saling menghormati, dan memiliki rasa tanggungjawab terhadap kewajibannya, sehingga mampu berinteraksi dalam kehidupan social yang majemuk dan heterogen (Rismayani, 2020:10). Menurut Susanto (dalam Putra, 2019:43) megemukakan bahwa pendidikan IPS di sekolah dasar merupakan bidang studi yang mempelajari manusia dalam semua aspek kehidupan dan interaksi dalam masayarakat. IPS sebagai mata pelajaran di SD memiliki tujuan untuk membantu siswa mengetahui perannya sebagai salah satu anggota masayarakat, mengembangkan potensi agar peka terhadap masalah sosial, serta sebagai warga negara baik dan bertanggung jawab.

Indikator dari tercapainya tujuan pembelajaran IPS di sekolah dapat dilihat dari prestasi belajar IPS siswa. Menurut Slameto (2003:2), bahwa belajar ialah "Suatu usaha yang dilakukan seseorang untuk memperoleh suatu perubahan tingkah laku yang baru secara keseluruhan, sebagai hasil pengalamannya sendiri dalam interaksi dengan lingkungannya". Pendapat tersebut menekankan bahwa belajar merupakan suatu bentuk usaha untuk perubahan tingkah laku sebagai hasil pengalaman berinteraksi dengan lingkungan. Sedangkan Harahap (dalam Djamarah, 1994), berpendapat bahwa prestasi adalah "penilaian pendidikan tentang perkembangan dan kemajuan siswa berkenaan dengan penguasaan bahan pelajaran yang disajikan kepada siswa". Pendapat tersebut menjelaskan bahwa prestasi merupakan sebuah penilaian yang berisi unsur perkembangan dan kemajuan siswa dalam pendidikan.

Berdasarkan pendapat di atas, dapat disimpulkan bahwa prestasi belajar IPS merupakan penilaian dari suatu usaha yang dilakukan seseorang untuk memperoleh suatu perubahan tingkah laku yang baru secara keseluruhan, sebagai hasil pengalamannya sendiri dalam kegiatan belajar IPS. Dalam proses pembelajaran IPS di sekolah tentunya dipengaruhi oleh berbagai macam faktor internal maupun eksternal dari siswa. Beberapa faktor tersebut misalnya konsep diri, motivasi belajar dan minat belajar siswa.

Konsep diri merupakan suatu konsep yang dimiliki oleh seorang individu tentang dirinya sendiri, serta menjadi pedoman seseorang dalam bertindak. Konsep diri menjadi faktor yang mendorong seseorang dalam memutuskan suatu pembelian, dimana dalam diri seseorang memiliki kebutuhan, dan kepuasaan yang dimilikinya, sehingga hal ini membentuk perilaku konsumtif individu. Hurlock (1994) mengemukakan beberapa kondisi yang mempengaruhi konsep diri pada masa kanak-kanak, yaitu: kondisi fisik, bentuk tubuh, nama dan julukan, status sosial ekonomi, lingkungan kampus, dukungan sosial, keberhasilan dan kegagalan, seks dan inteligensi, sedangkan kondisi yang mempengaruhi konsep diri pada masa remaja, yaitu: usia 
kematangan, penampilan diri, kepatutan seks, nama dan julukan, hubungan keluarga, teman sebaya, kreatifitas, dan cita-cita.

Selanjutnya motivasi di dalam kegiatan belajar merupakan kekuatan yang dapat menjadi tenaga pendorong bagi mahasiswa untuk mendayagunakan potensi-potensi yang ada pada dirinya dan potensi di luar dirinya untuk mewujudkan tujuan belajar. siswa yang memiliki motivasi belajar akan nampak melalui kesungguhan untuk terlibat dalam proses belajar, anatara lain nampak melalui keaktifan bertanya, mengemukakan pendapat, menyimpulkan pelajaran, mencatat, membuat resume, mempraktekan sesuatu, mengerjakan latihan-latihan dan evaluasi sesuai dengan tuntutan pembelajaran. Siswa yang tidak atau kurang memiliki motivasi belajar, umumnya kurang mampu bertahan untuk belajar lebih lama, kurang bersungguh-sungguh dalam mengerjakan tugas. Sikap yang kurang positif ini semakin nampak ketika tidak ada orang lain (guru, orang tua) yang mengawasinya. Oleh karena itu, rendahnya motivasi merupakan masalah dalam belajar, karena hal ini memberikan dampak bagi ketercapaian hasil belajar (prestasi belajar) yang diharapkan (Aunurrahman, 2011).

Minat merupakan salah satu faktor yang mempengaruhi siswa dalam belajar, dimana minat termasuk faktor intern dalam psikologis siswa. Adanya minat belajar yang baik yang terdapat dalam diri siswa, tentunya akan sangat berpengaruh terhadap minat belajar atau prestasi siswa.Suatu minat dapat diekspresikan melalui suatu pernyataan yang menunjukkan bahwa siswa lebih menyukai suatu hal daripada hal lainnya, dapat pula dimanifestasikan melalui partisipasi dalam suatu aktifitas.siswa yang memiliki minat terhadap subyek tertentu cenderung untuk memberikan perhatian yang lebih besar terhadap subyek tertentu.

Slameto $(2003 ; 180)$ mengemukakan bahwa minat adalah suatu rasa lebih suka dan rasa keterikatan pada suatu hal atau aktivita, tanpa ada yang menyuruh. Minat pada dasarnya adalah penerimaan akan suatu hubungan antara diri sendiri dengan sesuatu di luar diri.semakin kuat atau dekat hubungan tersebut, semakin besar minat. Minat besar pengaruhnya terhadap belajar, karena bila bahan pelajaran yang dipelajaritidak sesuai dengan minat siswa, siswa tidak akan belajar dengan baik, karena tidak ada daya tarik baginya. Bahan pelajaran yang menarik minat siswa, lebih mudah dipelajari dan disimpan, karena minat menambah kegiatan belajar. Jika terdapat siswa yang kurang berminat terhadap belajar, dapatlah diusahakan agar ia mempunyai minat yang lebih besar dengan cara menjelaskan hal-hal yang menarik dan berguna bagi kehidupan serta hal-hal yang berhubungan dengan cita-cita serta kaitannya dengan bahan pelajaran yang dipelajari itu.

Kontribusi konsep diri, motivasi belajar dan minat belajar terhadap prestasi belajar IPS siswa di sekolah sangat penting untuk diteliti. Mengingat realita pembelajaran IPS di SMP N 1 Mengwi terlihat bahwa guru kurang memperhatikan konsep diri, motivasi belajar, dan minat belajar siswa. Berdasarkan hasil observasi yang telah dilakukan pada pembelajaran IPS di SMPN 1 Mengwi, terlihat bahwa materi yang diajarkan dalam pembelajaran IPS cendrung hanya berupa sajian konsep yang terdapat dalam buku ajar atau LKS sehingga, pengetahuan siswa cendrung hanya sebatas pada materi yang terdapat pada buku LKS. Pembelajaran IPS yang diterapkan disekolah terkesan masih kaku, kurang fleksibel, berisi hafalan dan membosankan bagi siswa. Sebagian siswa dianggap mata pelajaran IPS sebagai mata pelajaran yang sulit dipahami sehingga, siswa cenderung merasa bosan, jenuh, malas untuk belajar, siswa kurang termotivasi karena siswa menggangap mata pelajaran IPS merupakan mata pelajaran yang bersifat hafalan, sehingga konsep diri, motivasi belajar, dan minat belajar siswa mnejadi kurang optimal.

Rendahnya konsep diri, motivasi belajar, dan minat belajar siswa dalam pembelajaran IPS di SMP N 1 Mengwi dapat dilihat dari Nilai Tahun Pelajaran 2019/2020, Semester Ganjil masih 
dibawah rata- rata siswa kelas VII hanya mencapai 63,25, sedangkan nilai KKM yang harus dicapai oleh siswa sebesar 67, rata- rata siswa kelas VIII hanya mencapai 65,49, sedangkan nilai KKM yang harus dicapai oleh siswa sebesar 69 dan rata- rata siswa kelas IX hanya mencapai 66,45, sedangkan nilai KKM yang harus dicapai oleh siswa sebesar 70 .

Tabel 1 Rata-rata Nilai Semester Ganjil Mata Pelajaran IPS SMP N 1 Mengwi

\begin{tabular}{cccc}
\hline No & Kelas & $\begin{array}{c}\text { Kreteria } \\
\text { Ketuntasan Minimum } \\
\text { (KKM) }\end{array}$ & $\begin{array}{c}\text { Nilai Rata- rata } \\
\text { Capaian Siswa }\end{array}$ \\
\hline 1 & VII & 67 & 63,25 \\
\hline 2 & VIII & 69 & 65,49 \\
\hline 3 & IX & 70 & 66,45 \\
\hline
\end{tabular}

Sumber: Dokumen Nilai SMP N 1 Mengwi Tahun Ajaran2019/2020

Fakta ini bisa diartikan bahwa siswa SMP N 1 Mengwi memiliki rendahnya kontribusi konsep diri, motivasi belajar, dan minat belajar siswa sehingga nilai yang mereka peroleh berada dibawah standar KKM.

Pada hal konsep diri, motivasi belajar dan minat belajar merupakan salah kunci pokok dalam kegiatan pembelajaran di kelas. Hal ini terbukti dari penelitian yang terdahulu yang dilakukan oleh Ardianti (2019) hasil penelitiannya menyatakan bahwa: konsep diri dan motivasi belajar secara bersama-sama maupun terpisah berpengaruh signifikan terhadap prestasi belajar Ilmu Pengetahuan Sosialsiswa di SMP Negeri di Kabupaten Serang. Selanjutnya penelitian yang dilakukan oleh Putri (2017) dalam penelitiannya disimpulkan bahwa ada pengaruh yang signifikan minat belajar terhadap prestasi belajar siswa kelas XI IPS SMA Negeri 1 Prajekan Kabupaten Bondowoso dengan kontribusi sebesar 47,57\%.

Berdasarkan pemaparan di atas, terlihat bahwa konsep diri, motivasi belajar dan minat belajar memiliki kontribusi yang sangat besar terhadap prestasi belajar IPS siswa. Seberapa besar kontribusi dari konsep diri, motivasi belajar dan minat belajar terhadap prestasi belajar IPS siswa di SMP N 1 Mengwi belum pernah dilakukan penelitian. Padahal hal ini sangat penting untuk dilakukan, dikarenakan dapat memberikan kontribusi yang positif terhadap perkembangan prestasi belajar IPS siswa di sekolah.

Mengingat pentingnya informasi tentang seberapa besar kontribusi dari konsep diri, motivasi belajar dan minat belajar terhadap prestasi belajar IPS siswa di SMP N 1 Mengwi, maka pada penelitian ini akan mengangkat judul tentang Kontribusi Konsep Diri, Motivasi Belajar Dan Minat Belajar Terhadap Prestasi Belajar IPS Siswa SMP N 1 Mengwi Tahun Pelajaran 2020/2021.

\section{Metode}

Penelitian ini termasuk penelitian Survey Studi Korelasi atau ex-post facto karena tidak dilakukan perlakuan pada variabel dan hanya mengambil data secara langsung. Lebih lanjut, 
penelitian ini termasuk pendekatan kuantitatif dengan rancangan korelasional karena dalam penelitian ini mencoba mengetahui kontribusi yang ada, antar variabel yang dikorelasikan (Koyan, 2012). Hasil penelitian hanyalah mendeskripsikan dan menganalisis kontribusi antara konsep diri, motivasi belajar, dan minat belajar terhadap prestasi belajar IPS.

Populasi dalam penelitian ini adalah seluruh siswadi SMP N 1 Mengwi Tahun Pelajaran 2020/2021 dengan jumlah 1.047siswa. Berdasarkan tabel Morgan, apabila populasi sebanyak 1.047 orang, maka sampel yang bisa digunakan untuk mewakilinya adalah 285 orang.

Dalam penelitian ini variabel bebas meliputi: konsep diri (X1), motivasi belajar (X2), dan minat belajar (X3). Sedangkan sebagai variabel terikat adalah prestasi belajar IPS (Y).

Untuk pengumpulan data tentang konsep diri, motivasi belajar, minat belajar digunakan kuesioner dengan pola skala likert. Sedangkan untuk memperoleh data tentang prestasi belajar IPS siswa digunakan metode dokumen.

Berdasarkan validasi isi yang telah dilakukan pada dua orang pakar, didapatkan hasil bahwa seluruh butir kuesioner konsep diri, motivasi belajar, dan minat belajar dinyatakan valid, sehingga validitas isi kuesioner konsep diri, motivasi belajar, dan minat belajar mendapatkan koefisien 1, yang menandakan kuesioner konsep diri, motivasi belajar, dan minat belajar pada penelitian ini memiliki validitas sangat tinggi.

Sedangkan berdasarkan validitas butir yang telah dilakukan didapatkan hasil bahwa kuesioner konsep diri dan motivasi belajar dinyatakan bahwa seluruh butirnya valid. Sedangkan kuesioner minat belajar 33 butir dinyatakan valid dan 1 butir dinyatakan gugur. Berdasarkan analisis reliabilitas instrument yang telah dilakukan, didapatkan hasil bahwa kuesioner konsep diri, motivasi belajar, dan minat belajar masing-masing kuesioner memiliki tingkat reliabilitas sangat tinggi. Dalam melakukan analisis data untuk penelitian ini ada tiga tahapan yang dilalui yakni: 1) tahap deskripsi data, 2) tahap pengujian persyaratan analisis, dan 3) tahapan pengujian hipotesis. Seluruh analisis yang dilakukan pada penelitian ini dibantu dengan program SPSS.

\section{Hasil dan Pembahasan}

Terdapat Kontribusi yang Signifikan Konsep Diri, Motivasi Belajar, dan Minat Belajar terhadap Prestasi Belajar IPS Siswa SMP N 1 Mengwi Tahun Pelajaran 2020/2021. Hasil pengujian hipotesis pertama, mendapatkan hasil sebagai berikut.

Tabel 1.

Uji Signifikansi Persamaan Regresi Konsep Diri, Motivasi Belajar, dan Minat Belajar Terhadap Prestasi Belajar IPS.

\begin{tabular}{lcccccc}
\hline \multirow{2}{*}{$\begin{array}{c}\text { Sumber } \\
\text { variasi }\end{array}$} & $\mathrm{JK}$ & $\mathrm{dk}$ & $\mathrm{RJK}$ & F hitung & $\begin{array}{c}\text { F tabel } \\
\alpha= \\
0,05\end{array}$ & \\
\hline Regression & 5371,815 & 3 & 1790,605 & 151,509 & 3,88 & Signifikan \\
\hline Residual & 3320,992 & 281 & 11,818 & & & \\
\hline Total & 8692,807 & 284 & & & & \\
\hline
\end{tabular}

Keterangan:

$\mathrm{dk}=$ derajat kebebasan

$\mathrm{Jk}=$ jumlah kuadrat

$\mathrm{Rjk}=$ rerata jumlah kuadrat 
Berdasarkan pengujian hipotesis pertama yang telah dilakukan, didapatkan garis regresi $\hat{y}$ $=16,205+0,229 \cdot X 1+0,132 \cdot X 2+0,169 \cdot X 3$ dengan Freg $=151,509(p<0,05)$. Hasil ini menunjukkan hasil yang signifikan, sehingga dapat disimpulkan bahwa terdapat kontribusi yang signifikan konsep diri, motivasi belajar, dan minat belajar terhadap prestasi belajar IPS Siswa SMP N 1 Mengwi tahun pelajaran 2020/2021 dengan kontribusi sebesar 61,81\%.

Hasil penelitian ini diperkuat dengan hasil penelitian yang dilakukan oleh Ardianti (2019) dengan judul Pengaruh Konsep Diri Dan Motivasi Belajar Terhadap Prestasi Belajar IPS Siswa SMP Negeri di Kabupaten Serang. Hasil uji hipotesis menyeluruh ini: (1) konsep diri dan motivasi belajar secara bersama-sama berpengaruh signifikan terhadap prestasi belajar Ilmu Pengetahuan Sosial. Hal ini dibuktikan dengan perolehan nilai Sig. 0,00< 0,05 dan $\mathrm{Fh}=20,842$ dengan kontribusi X1 \& X2 sebesar 37,3\% terhadap Y; (2) konsep diri berpengaruh secara signifikan terhadap prestasi belajar Ilmu Pengetahuan Sosial. Hal tersebut dibuktikan dengan perolehan nilai Sig. $0,001<0,05$ da th $=3,584$ dan; (3) motivasi belajar berpengaruh secara signifikan terhadap prestasi belajar Ilmu Pengetahuan Sosial. Hal ini dibuktikan dengan perolehan nilai Sig. 0,00<0,05 da th $=3,802$. Hasil penelitian menunjukkan bahwa konsep diri dan motivasi belajar memiliki pengaruh yang signifikan terhadap hasil atau prestasi belajar siswa di SMP Negeri di Kabupaten Serang.

Selanjutnya penelitian Ritonga (2017) dengan judul Hubungan Minat Belajar Dan Konsep Diri Terhadap Prestasi Belajar Siswa. Dalam penelitiannya dinyatakan bahwa Dari hasil analisis data untuk menguji hipotesis dengan menggunakan t-test antara minat belajar dengan pembelajaran pencapaian diperoleh $t$ hitung $=3,758$ dengan sig. 0,000 $<0,05$ dan konsep diri prestasi belajar diperoleh t hitung $=3,205$ dengan sig. 0,002 $<0,05$. Untukmenguji hipotesis secara simultan diperoleh $\mathrm{F}$ hitung sebesar 17.900 sedangkan $\mathrm{F}$ tabel pada 3,16 tingkat signifikan 95\%. Ternyata Fhitung > Ftabel 35.310> 3.16. Ada hubungan yang positif dan signifikan secara parsial dan simultan antara minat belajar dan konsep diri terhadap prestasi belajar siswa kelas X IPS MAN Kisaran Tahun Akademik 2016/2017. Berdasarkan hasil analisis data dapat disimpulkan bahwa ada yang positif dan signifikan. Pengaruh antara Hubungan Minat Belajar dan Konsep Diri Prestasi Siswa pada 0,553 yang berarti berkontribusi 55,3\%.

Menurut Banks (dalam Lasmawan, 2016:58-59) karakteristik IPS adalah sebagai berikut. a) IPS mempunyai tujuan utama membentuk warga negara yang memiliki pengetahuan, ketrampilan-ketrampilan dan sikap yang dibutuhkan siswa dalam suatu masyarakat yang demokratis; b) IPS membantu siswa dalam mengkonstruk pengetahuan dan sikap dari disiplin akademik sebagai suatu pengalaman khusus; dan c) IPS mencerminkan perubahan pengetahuan, mengembangkan sesuatu yang baru dan menggunakan pendekatan terintegrasi untuk memecahkan isu secara manusiawi.

Dalam proses pembelajaran IPS di kelas, guru hendaknya mampu memotivasi siswa dalam pembelajaran. Upaya yang dapat dilakukan adalah dengan menggunakan berbagai macam model pembelajaran dan media pembelajaran yang mampu membuat siswa aktif dalam proses pembelajaran. Hal ini bertujuan agar minat belajar IPS siswa menjadi meningkat. Apabila minat belajar siswa sudah meningkat dalam pembelajaran IPS, tentunya akan berdampak positif terhadap peningkatan prestasi belajar IPS siswa di kelas.

Prestasi belajar IPS siswa adalah penilaian terhadap kegiatan belajar IPS siswa. Dalam pembelajaran IPS siswa tentunya dipengaruhi oleh banyak faktor internal maupun eksternal. Faktor tersebut misalnya konsep diri, motivasi belajar, dan minat belajar. Ketiga faktor tersebut sangat mempengaruhi semangat siswa belajar di kelas. Semakin tinggi konsep diri, motivasi belajar, dan minat belajar siswa maka siswa akan semakin bersemangat dalam belajar. Berdasarkan hal tersebut dapat disimpulkan bahwa terdapat kontribusi yang signifikan konsep diri, motivasi belajar, dan minat belajar terhadap prestasi belajar IPS siswa. 
Terdapat Kontribusi yang Signifikan Konsep Diri Terhadap Prestasi Belajar IPS Siswa SMP N 1 Mengwi Tahun Pelajaran 2020/2021. Hasil pengujian hipotesis kedua, mendapatkan hasil sebagai berikut.

Tabel 2.

Uji Signifikansi dan Kelinieran Regresi Prestasi Belajar IPS atas Konsep Diri

\begin{tabular}{|c|c|c|c|c|c|c|}
\hline \multirow[b]{2}{*}{$\begin{array}{c}\text { Sumber } \\
\text { variasi }\end{array}$} & \multirow[b]{2}{*}{ JK } & \multirow[b]{2}{*}{$\mathrm{dk}$} & \multirow[b]{2}{*}{ RJK } & \multirow[b]{2}{*}{ F hitung } & F tabel & \multirow[b]{2}{*}{ Keterangan } \\
\hline & & & & & $\begin{array}{c}\alpha= \\
0.05\end{array}$ & \\
\hline Regression & 3234,721 & 1 & 3234,721 & 167,719 & 3,88 & Signifikan \\
\hline Residual & 5458,086 & 283 & 19,287 & & & \\
\hline Total & 8692,807 & 284 & & & & \\
\hline
\end{tabular}

Keterangan:

$\mathrm{dk}=$ derajat kebebasan

$\mathrm{Jk}=$ jumlah kuadrat

Rjk = rerata jumlah kuadrat

Berdasarkan pengujian hipotesis kedua yang telah dilakukan, didapatkan garis regresi $\hat{y}=$ $3,129+0,636 X 1$ dengan Freg $=167,719(p<0,05)$. Hasil ini menunjukkan hasil yang signifikan, sehingga dapat disimpulkan bahwa terdapat kontribusi yang signifikan konsep diri terhadap prestasi belajar IPS Siswa SMP N 1 Mengwi tahun pelajaran 2020/2021 dengan kontribusi sebesar $37,2 \%$ dan sumbangan efektif sebesar 13,40\%.

Hasil penelitian ini diperkuat dengan hasil penelitian yang dilakukan oleh Saragi (2016) dengan judul Kontribusi Konsep Diri Dan Dukungan Orang Tua Terhadap Motivasi Belajar Siswa dan Implikasinya Dalam Pelayanan Bimbingan Dan Konseling. Dalam penelitiannya disimpulkan bahwa konsep diri dan dukungan orangtua memberikan kontribusi secara bersama-sama terhadap motivasi belajar siswa sebesar 30.7\%. Artinya, semakin tinggi kontribusi konsep diri dan dukungan orangtua secara bersama-sama maka semakin tinggi pula motivasi belajar siswa.

Keberhasilan pelaksanaan proses pembelajaran IPS di sekolah tidak terlepas dari peran guru sebagai seorang fasilitator, motivator, dan inspirator, bukan guru orator, apalagi yang otoriter dan dominan. Para guru harus menempatkan dirinya setara dengan para siswanya, yang membedakan hanya fungsinya. Disamping itu guru harus berkelakuan baik sesuai dengan harapan masyarakat. Dari guru, sebagai pendidik dan pembangun generasi baru diharapkan tingkah laku yang bermoral tinggi demi masa depan bangsa dan negara. Kepribadian guru dapat mempengaruhi suasana kelas atau sekolah, baik kebebasan yang dinikmati anak dalam mengeluarkan buah pikiran, dan mengembangkan kreatifitasnya ataupun pengekangan dan keterbatasan yang dialami dalampengembangan pribadinya. Hal ini tentunya akan mempengaruhi pembangunan konsep diri siswa dalam pembelajaran IPS yang diterapkan guru di kelas (Listyarti, 2012).

Konsep diri merupakan suatu konsep yang dimiliki oleh seorang individu tentang dirinya sendiri, serta menjadi pedoman seseorang dalam bertindak. Konsep diri menjadi faktor yang mendorong seseorang dalam memutuskan suatu pembelian, dimana dalam diri seseorang memiliki kebutuhan, dan kepuasaan yang dimilikinya, sehingga hal ini membentuk perilaku konsumtif individu. Apabila siswa memiliki konsep diri yang tinggi tentunya akan mengetahui hal yang baik untuk dirinya. Salah satu hal tersebut adalah belajar. Dari hal itu maka dapat disimpulkan bahwa terdapat kontribusi yang signifikan konsep diri terhadap prestasi belajar IPS siswa. 
Terdapat Kontribusi yang Signifikan Motivasi Belajar Terhadap Prestasi Belajar IPS Siswa SMP N 1 Mengwi Tahun Pelajaran 2020/2021. Hasil pengujian hipotesis ketiga, mendapatkan hasil sebagai berikut.

Tabel 3.

Uji Signifikansi dan Kelinieran Regresi Prestasi Belajar IPS atas Motivasi Belajar

\begin{tabular}{|c|c|c|c|c|c|c|}
\hline \multirow[b]{2}{*}{$\begin{array}{c}\text { Sumber } \\
\text { variasi }\end{array}$} & \multirow[b]{2}{*}{ JK } & \multirow[b]{2}{*}{$\mathrm{dk}$} & \multirow[b]{2}{*}{ RJK } & \multirow[b]{2}{*}{ F hitung } & F tabel & \multirow[b]{2}{*}{ Keterangan } \\
\hline & & & & & $\begin{array}{c}\alpha= \\
0.05\end{array}$ & \\
\hline Regression & 4748,508 & 1 & 4748,508 & 340,701 & 3,88 & Signifikan \\
\hline Residual & 3944,299 & 283 & 13,937 & & & \\
\hline Total & 8692,807 & 284 & & & & \\
\hline
\end{tabular}

Keterangan:

$\mathrm{dk}=$ derajat kebebasan

$\mathrm{Jk}=$ jumlah kuadrat

$\mathrm{Rjk}=$ rerata jumlah kuadrat

Berdasarkan pengujian hipotesis ketiga yang telah dilakukan, didapatkan garis regresi $\hat{y}=$ $44,045+0,334 X 2$ dengan Freg $=340,701(\mathrm{p}<0,05)$. Hasil ini menunjukkan hasil yang signifikan, sehingga dapat disimpulkan bahwa terdapat kontribusi yang signifikan motivasi belajar terhadap prestasi belajar IPS Siswa SMP N 1 Mengwi tahun pelajaran 2020/2021 dengan kontribusi sebesar $54,6 \%$ dan sumbangan efektif sebesar $21,62 \%$.

Hasil penelitian ini diperkuat dengan hasil penelitian yang dilakukan oleh Fau (2016) dengan judul Kontribusi Konsep Diri Akademik dan Motivasi terhadap Prestasi Belajar Bahasa Inggrisserta Implikasinya dalam Penyusunan Program Pelayanan Bimbingan dan Konseling di Bidang Belajar. Dalam penelitiannya disimpulkan bahwa: 1) Konsep diri akademik memberikan kontribusi terhadap prestasi belajar Bahasa Inggris siswa sebesar 20,3\%, 2) Motivasi memberikan kontribusi terhadap prestasi belajar Bahasa Inggris siswa sebesar 32,9\%, dan 3) Konsep diri akademik dan motivasi memberikan kontribusi terhadap prestasi belajar Bahasa Inggris siswa secara bersama-sama sebesar 60,1\%.

Motivasi dapat juga dikatakan serangkaian usaha untuk menyediakan kondisi-kondisi tertentu, sehingga seseorang mau dan ingin melakukan sesuatu, dan bila ia tidak suka, maka akan berusaha untuk meniadakan atau mengelakkan perasaan tidak suka itu. Motivasi dapat dirangsang oleh faktor dari luar tetapi motivasi adalah tumbuh di dalam diri seseorang. Dalam kegiatan belajar, motivasi dapat dikatakan sebagai keseluruhan daya penggerak di dalam diri siswa yang menimbulkan kegiatan belajar, yang menjamin kelangsungan dari kegiatan belajar dan yang memberikan arah pada kegiatan belajar, sehingga tujuan yang dikehendaki oleh subjek belajar itu dapat tercapai (Sardiman, 2007).

Motivasi di dalam kegiatan belajar juga merupakan kekuatan yang dapat menjadi tenaga pendorong bagi siswa untuk mendayagunakan potensi-potensi yang ada pada dirinya dan potensi di luar dirinya untuk mewujudkan tujuan belajar. siswa yang memiliki motivasi belajar akan nampak melalui kesungguhan untuk terlibat dalam proses belajar, anatara lain nampak melalui keaktifan bertanya, mengemukakan pendapat, menyimpulkan pelajaran, mencatat, membuat resume, mempraktekan sesuatu, mengerjakan latihan-latihan dan evaluasi sesuai dengan tuntutan pembelajaran. Siswa yang tidak atau kurang memiliki motivasi belajar, umumnya 
kurang mampu bertahan untuk belajar lebih lama, kurang bersungguh-sungguh dalam mengerjakan tugas. Sikap yang kurang positif ini semakin nampak ketika tidak ada orang lain (guru, orang tua) yang mengawasinya. Oleh karena itu, rendahnya motivasi merupakan masalah dalam belajar, karena hal ini memberikan dampak bagi ketercapaian hasil belajar (prestasi belajar) yang diharapkan (Aunurrahman, 2011). Berdasarkan hal itu dapat disimpulkan bahwa terdapat kontribusi yang signifikan motivasi belajar terhadap prestasi belajar IPS siswa.

Terdapat Kontribusi yang Signifikan Minat Belajar Terhadap Prestasi Belajar IPS Siswa SMP N 1 Mengwi Tahun Pelajaran 2020/2021. Hasil pengujian hipotesis keempat, mendapatkan hasil sebagai berikut.

Tabel 4.

Uji Signifikansi dan Kelinieran Regresi Prestasi Belajar IPS atas Minat Belajar

\begin{tabular}{lcccccc}
\hline $\begin{array}{l}\text { Sumber } \\
\text { variasi }\end{array}$ & $\mathrm{JK}$ & $\mathrm{dk}$ & $\mathrm{RJK}$ & F hitung & $\begin{array}{c}\text { F tabel } \\
\alpha= \\
\text { Keterangan }\end{array}$ & \\
\hline Regression & 4824,319 & 1 & 4824,319 & 352,924 & 3,88 & Signifikan \\
\hline Residual & 3868,488 & 283 & 13,670 & & & \\
\hline Total & 8692,807 & 284 & & & & \\
\hline
\end{tabular}

Keterangan:

$\mathrm{dk}=$ derajat kebebasan

$\mathrm{Jk}=$ jumlah kuadrat

$\mathrm{Rjk}=$ rerata jumlah kuadrat

Berdasarkan pengujian hipotesis keempat yang telah dilakukan, didapatkan garis regresi $\hat{y}$ $=36,900+0,350 X 3$ dengan Freg $=352,924(\mathrm{p}<0,05)$. Hasil ini menunjukkan hasil yang signifikan, sehingga dapat disimpulkan bahwa terdapat kontribusi yang signifikan minat belajar terhadap prestasi belajar IPS Siswa SMP N 1 Mengwi tahun pelajaran 2020/2021 dengan kontribusi sebesar $55,5 \%$ dan sumbangan efektif sebesar $26,79 \%$.

Hasil penelitian ini diperkuat dengan hasil penelitian yang dilakukan oleh Putri (2017) dengan judul Pengaruh Minat Belajar Dan Kecerdasan Emosional Terhadap Prestasi Belajar Siswa Kelas XI IPS SMA Negeri 1 Prajekan Kabupaten Bondowoso Tahun Ajaran 2016/2017. Dalam penelitiannya disimpulkan bahwa ada pengaruh yang signifikan minat belajar dan kecerdasan emosional terhadap prestasi belajar siswa kelas XI IPS SMA Negeri 1 Prajekan Kabupaten Bondowoso Tahun Ajaran 2016/2017 yaitu sebesar83,3\%.Untuk pengaruh yang dominan terhadap prestasi belajar siswa kelas XI IPS SMA Negeri 1 Prajekan Kabupaten Bondowoso Tahun Ajaran 2016/2017 yaitu pada variabel minat belajar (X1) sebesar 47,57\%.

Minat memegang peranan penting dalam kehidupan siswa dan mempunyai dampak yang besar atas perilaku dan sikapnya. Minat menjadi sumber motivasi yang kuat untuk belajar. Siswa yang berminat terhadap pelajaran, maka akan berusaha sekuat tenaga untuk mencapai tujuan yang diinginkan (Agustina, 2015). Slameto $(2003 ; 180)$ mengemukakan bahwa minat adalah suatu rasa lebih suka dan rasa keterikatan pada suatu hal atau aktivitas, tanpa ada yang menyuruh. Minat pada dasarnya adalah penerimaan akan suatu hubungan antara diri sendiri dengan sesuatu di luar diri. Semakin kuat atau dekat hubungan tersebut, semakin besar minat tersebut. 
Dalam kegiatan belajar, siswa yang memiliki minat belajar yang tinggi, tentunya akan berusaha untuk belajar dengan bersungguh-sungguh dan materi pembelajaran akan dapat dikuasainya secara optimal. Hal ini tentunya berdampak yang positif terhadap prestasi belajar siswa di sekolah. Semakin tinggi minat belajar siswa terhadap pembelajaran IPS di sekolah, tentunya semakin tinggi pula prestasi belajar IPS yang diraih siswa di sekolah. Berdasarkan hal itu dapat disimpulkan bahwa terdapat kontribusi yang signifikan minat belajar terhadap prestasi belajar IPS siswa.

\section{Simpulan dan Saran}

Berdasarkan penelitian yang telah dilakukan, dapat disimpulkan hal-hal sebagai berikut. Terdapat kontribusi yang signifikan konsep diri, motivasi belajar, dan minat belajar terhadap prestasi belajar IPS siswa SMP N 1 Mengwi tahun pelajaran 2020/2021, dengan kontribusi sebesar $61,81 \%$. Terdapat kontribusi yang signifikan konsep diri terhadap prestasi belajar IPS siswa SMP N 1 Mengwi tahun pelajaran 2020/2021, dengan kontribusi sebesar 37,2\% dan sumbangan efektif sebesar 13,40\%. Terdapat kontribusi yang signifikan motivasi belajar terhadap prestasi belajar IPS siswa SMP N 1 Mengwi tahun pelajaran 2020/2021, dengan kontribusi sebesar 54,6\% dan sumbangan efektif sebesar 21,62\%. Terdapat kontribusi yang signifikan minat belajar terhadap prestasi belajar IPS siswa SMP N 1 Mengwi tahun pelajaran 2020/2021, dengan kontribusi sebesar 55,5\% dan sumbangan efektif sebesar $26,79 \%$.

Dari penelitian yang telah dilakukan, dapat disampaikan beberapa saran sebagai berikut. Siswa disarankan untuk selalu bersemangat belajar dan selalu meningkatkan konsep diri, motivasi belajar serta minat belajarnya, sehingga prestasi belajar IPS siswa dapat ditingkatkan secara optimal. Guru disarankan untuk selalu memperhatikan konsep diri, motivasi belajar serta minat belajar siswa dalam proses pembelajaran, sehingga tujuan pembelajaran khususnya pembelajaran IPS dapat tercapai. Sekolah disarankan untuk selalu mendukung segala peningkatkan sumber daya yang ada di sekolah, sehingga akan mampu meningkatkan kualitas pendidikan yang berlangsung di sekolah. Peneliti lain disarankan untuk menggunakan penelitian ini sebagai pedoman dan rujukan pada penenelitian selanjutnya.

\section{Daftar Pustaka}

Agustina, S., \& T. M. (2015). Hubungan Konsep Diri, Motivasi Berprestasi, Dengan Hasil Belajar Mahasiswa. Jurnal Education, 10(2), 501-512.

Ardianti, T. (2019). Pengaruh Konsep Diri Dan Motivasi Belajar Terhadap Prestasi Belajar IPS Siswa SMP Negeri di Kabupaten Serang. Jurnal Selaras, 2(1).

Aunurrahman. (2011). Belajar dan Pembelajaran. Bandung: Alfabeta.

Djamarah, S. B. (1994). Prestasi Belajar dan Kompetensi Guru. Surabaya: Usaha Nasional.

Fau, S. (2016). Kontribusi Konsep Diri Akademik dan Motivasi terhadap Prestasi Belajar Bahasa Inggrisserta Implikasinya dalam Penyusunan Program Pelayanan Bimbingan dan Konseling di Bidang Belajar. Jurnal Konselor, 5(4).

Hurlock, E. B. (1994). Psikologi Perkembangan.Edisi V. Jakarta: Erlangga.

Ibrahim. (2000). Pembelajaran Kooperatif. Surabaya: University Press.

Koyan, I. W. (2012). Statistik Pendidikan. Singaraja: Universitas Pendidikan Ganesha Press.

Lasmawan, I. W. (2016). Pendidikan IPS. Singaraja: Mediakom Indonesia Press.

Listyarti, R. (2012). Pendidikan Karakter Dalam Metode Aktif, Inovatif, Dan Kreatif. Jakarta: Esensi.

Putra, I K. R. D. (2019). Pengaruh Model Pembelajaran Quantum Learning Berbantuan Peta Pikiran Terhadap Kemampuan Berpikirkreatif Dan Hasil Belajar IPS Siswa Kelas V. Jurnal Pendidikan IPS Indonesia, 3(1), 43.

Putri, K. D. (2017). Pengaruh Minat Belajar Dan Kecerdasan Emosional Terhadap Prestasi Belajar Siswa Kelas XI IPS SMA Negeri 1 Prajekan Kabupaten Bondowoso Tahun Ajaran 
2016/2017. Jurnal Ilmiah Ilmu Pendidikan, Ilmu Ekonomi, Dan Ilmu Sosial, 11(1).

Raga, G. D. (2006). Konsep Dasar Ilmu Pengetahuan Sosial. Singaraja: Undiksha.

Rahmad. (2016). Kedudukan Ilmu Pengetahuan Sosial (IPS) Pada Sekolah Dasar. Jurnal Penddikan Guru Madrasah Ibtidaiyah, 2(1), 71.

Rismayani, L. D. (2020). Penanaman Sikap Sosial Melalui Pembelajaran IPS. Jurnal Pendidikan IPS Indonesia, 4(1), 10.

Ritonga, M. F. M. (2017). Hubungan Minat Belajar Dan Konsep Diri Terhadap Prestasi Belajar Siswa. Jurnal EducanduM, 10(1).

Rusmini. (2017). Peningkatan Mutu Sumber Daya Manusia Melalui Pendidikan Karakter dan Attitude. Jurnal Nur EL-Islam, 4(2), 80.

Saragi, M. P. D. (2016). Kontribusi Konsep Diri Dan Dukungan Orang Tua Terhadap Motivasi Belajar Siswa dan Implikasinya Dalam Pelayanan Bimbingan Dan Konseling. Jurnal Konselor, 5(1).

Sardiman. (2007). Interaksi dan Motivasi Belajar Mengajar. Jakarta: PT. Raja Grafindo Persada. Slameto. (2003). Belajar dan Faktor-faktor yang Mempengaruhinya. Jakarta: Rineka Cipta. Susanto, A. (2014). Pengembangan Pembelajaran IPS di SD. Jakarta: Prenadamedia Grup. 